\title{
Application and Effectiveness of New Public Management in National Water and Sewerage Corporation
}

Mukokoma M. Maurice

Worldwide, public utilities are undergoing reforms, including the adoption of New Public Management (NPM) - a managerial strategy that departs from monopolistic forms of public utilities to argue for the adoption of market-oriented approaches to the provision of social services. In Uganda, National Water and Sewerage Corporation (NWSC) is reported to be applying principles of the strategy. Hitherto, however, research had not been conducted into whether the corporation's management typifies the application of these principles and, if it does, what the results of doing so have been. This study was, therefore, conducted to examine the application of these principles in the corporation and assess the level of customers' satisfaction with the corporation's services, with the view to highlight the link between the two, if any. Data were collected through documentary analysis; survey of the corporation's customers' satisfaction with its services; and interview, of some of the corporation's managers. The findings were that, with a few exceptions, the corporation applies the principles of NPM (i.e. autonomy, accountability, customer orientation and market orientation); and that the application of these principles has enhanced customer satisfaction. It is, therefore, recommended that the corporation increases its adherence to the principles. In addition, NPM is recommended to organizations that are similar to NWSC.

Key words: NPM; Customer satisfaction; NWSC; Public sector reform

\section{Introduction}

NPM, a managerial strategy that departs from monopolistic forms of public utilities to argue for a wide range of service providers and adoption of market-oriented approaches (Stoker, 2006:45), developed in response to perceived weaknesses in the traditional bureaucratic paradigm of public administration and service delivery. The proponents of the strategy argue that it leads to improvement in the management of public institutions. Uganda's National Water and Sewerage Corporation (NWSC) has been cited as implementing principles of the strategy (see, for example, Schwartz, 2008). Hitherto, however, no empirical research had been conducted into the way(s) in which the organization implements the strategy and whether the application of the strategy has been related to customer satisfaction. This study was, therefore, carried out to examine the application of NPM principles in the organization; assess the level of customers' satisfaction with the organization's services; and examine the link between the application of the principles and customers' satisfaction with the organization's services. It was carried out through documentary analysis, survey, of the corporation's customers, and interview of some of the corporation's managers. The findings were that the corporation applies the principles of

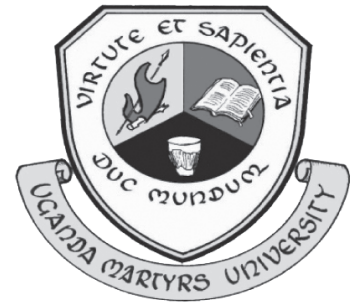

Journal of Science and Sustainable Development Copyright (C) 2009 Uganda Martyrs University ISSN: 2070-1748; Vol 2 (1): 61-67 www.umu.ac.ug 
NPM investigated (i.e. autonomy, accountability, customer orientation and market orientation); and that the application of these principles has enhanced customer satisfaction. Thus, increased adherence to the principles is recommended to the corporation. In addition, NPM is recommended to organizations that are similar to NWSC.

\section{Related Literature}

NPM is a market-oriented and output-based management model that emphasizes accountability for results and customer-orientation (Peters, 1996; Kettl, 2000; Harrow 2002). Its origins can be traced to the early 1980s, in New Zealand and the United Kingdom. Over the years, many authors (e.g. Hood, 1991; Pollitt, 1993; Walsh, 1995; Hughes, 2006; Stoker, 2006; Van Dijk, 2006; Schwartz 2008) have tried to describe the model. For example, Hood (1991) set out its key principles as hands-on professional management; explicit standards and measures of performance; segregation of units; market orientation; and output controls. Nonetheless, these characteristics have changed over time. For instance, Pollitt (1993) and Walsh (1995) analyzed the model in terms of the extent to which managers are given 'the right to manage' and considered such variables as increases in efficiency, use of improved technologies, workers that are disciplined towards productivity, clear implementation of the professional management role, improvements in the quality of service delivery, emphasis on delegation, use of appropriate information systems, emphasis on contracts/markets and measurement of performance. Notwithstanding the difference between this characterization and that advanced by Hood (1991), they both focus on markets and competition; managerial improvement; autonomy; and accountability. Hughes (2006) articulated four grand themes characterizing NPM, namely, management, economic principles, modern management theory and practices and service delivery. He argues that managerial responsibility should be based on the economic principles of public choice, principal-agent relationships, contracting and competition, adding that flexibility in staffing and organization can improve public management and service delivery. On the other hand, Van Dijk (2006) identifies five principles of NPM. These are autonomy, accountability, customer orientation, corporate culture and market orientation. Several researchers (e.g. Schwartz, 2008; Hood, 1991) concur with this characterization. Grounded on this congruity, therefore, the study conceptualized NPM in terms of four of these principles, namely, autonomy, accountability, customer orientation and market orientation.

Autonomy describes a situation in which an organization has the resources and managerial freedom that it needs to fulfil its mandate. Thus, it focuses on internal and external decentralization, which has been found to increase performance (particularly financial) (see, for example, Islam 1993, Hoffer 1995, Batley 1999, Schwartz 2006, Okke et al. 2007). According to Von Weizsacker et al. (2005) and Gleick et al. cited by Kjellen (2006), the level of organizational autonomy may be analyzed along a public-private continuum as is shown in Table 1.

Table 1: Level of Autonomy by Nature of Organization

\begin{tabular}{|l|l|l|}
\hline Nature of Organization & Utility Service Delivery & Level of Autonomy \\
\hline Government agency & \multirow{2}{*}{ Direct public management } & Low \\
Parastatal & Indirect public management & $\begin{array}{l}\text { Moderate (depending on } \\
\text { nature of arrangement; } \\
\text { parties involved; and } \\
\text { nature of contracts } \\
\text { adopted). }\end{array}$ \\
\cline { 1 - 1 } Service contract & Delegated private management & High \\
\cline { 1 - 1 } Management contract & Dease contract & \\
\cline { 1 - 1 } Concession & &
\end{tabular}


Organizational autonomy has been found to be positively, and strongly, related to performance (Okke, et al., 2007). Subsequently, the study undertook to establish the extent to which NWSC is autonomous, using the public-private continuum depicted in Table 1 as a framework. Closely linked to autonomy is the principle of accountability, which refers to the condition of holding organizations, and managers, to whom autonomy is granted, responsible for their performance (Islam, 1993; Pollit et al., 1998). To this end, Yepes (1990) argues, and plausibly so, that accountability, which involves the setting of goals against verifiable indicators in whose terms performance is appraised, helps organizations to improve their efficiency and effectiveness. Regarding customer orientation, Osborne and Gaebler (1992) observe that the concept is foreign to organizations involved in the provision of public utilities, since these organizations usually portray a service, rather than customer, based culture whereby focus is on government's, as opposed to customer's, satisfaction. Under NPM, however, there is a connection between increasing the organization's income, from the levy of user fees, and the need to improve customer orientation (Awortwi, 2003), which leads to increased customer pressure and, subsequently, improved, and accountable, service delivery (Batley, 1999; Bovaird, 2006; Van Dijk, 2006; Yepes, 1990). Finally, market orientation points to the adoption of mechanisms that are aligned to the market. Internally, these mechanisms introduce competition into the organization while externally they introduce cooperation and competition with other organizations, all of which lead to better performance (Jaworski \& Koli, 1990; Lavery, 1999; Warner \& Hedbon, 2001). Therefore, the study investigated the adoption of such mechanisms at NWSC.

\section{Method}

Data were collected from Kampala NWSC Area, which was purposely selected because it accounts for over $70 \%$ of the corporation's activities. This was done through documentary analysis, interviews and administration of a 'customer satisfaction questionnaire'. Specifically, information, on the management environment and practices of the corporation, was culled from the NWSC Act, 2000; NWSC annual activity and performance reports, from 2003 to 2008; and NWSC performance contracts, with government and the corporation's subcontractors. To examine the application of NPM principles in the corporation, interviews were held with eleven (11) managers, from the zones in Kampala NWSC Area; and four (4) managers, at the corporation's head office. This was done using a guide that was based on the principles of NPM outlined by Swartz (2006). Finally, the 'customer satisfaction questionnaire' was administered to 295 NWSC customers, $97 \%$ of whom returned it. The number of customers selected, per zone, was determined as a percentage of the total number of customers in the zone, after which the individual respondents were randomly selected, using the customer database (maintained by the corporation) as a sampling frame. Using content analysis, the data from the documents and interviews were analyzed in triangulation, to highlight the reference to NPM and customer satisfaction in the documents analyzed and interviews recorded. The data elicited by the 'customer satisfaction questionnaire' were analyzed using frequency counts and percentages.

\section{Findings and Discussion}

In the following subsections, the findings on the application of the principles of NPM studied in NWSC are presented, by the principles, after which the results of the customer satisfaction survey are presented.

Autonomy: the findings were that the contractual arrangements between the Government of Uganda and NWSC make the latter highly autonomous, notwithstanding its nature as a publicly owned corporation. It was established that the National Water \& Sewerage Corporation Act (2000) strengthened the legal framework of NWSC and consequently increased its autonomy. The Act mandated the organization to operate and provide water and sewerage services in the areas entrusted to it on a commercially sound and viable basis; and apart from providing a legal framework, government does not interfere with the 
activities its activities. This is in contrast with the situation before the adoption of NPM, when the corporation had limited autonomy coupled with heavy bureaucratic reporting procedures (Mugisha and Berg, 2006) let alone ambiguous responsibility lines and mandate overlaps, with various agencies and ministries. The interviewees revealed that the corporation enjoys autonomy in decision making; financial autonomy, in principle self-reliance; and autonomy in staffing, with the freedom to attract and maintain staff. Nonetheless, the interviewees revealed that the organization has limited autonomy from government when it comes to the setting of tariffs.

Accountability: it was found that, externally, the performance of NWSC is guided by its three-year performance contract with the Government of Uganda, which stipulates performance indicators (e.g. collection efficiency, service coverage, unaccounted-for-water [UfW], financial and operating efficiency and requirements to develop a customer policy and implement a customer charter). The contract is monitored by the Contract Review Committee and the top management of the corporation is accountable to the Board of Directors, based on the performance targets set in the contract. It was noted that, for donor-funded projects, NWSC is accountable to the donors and that it gives them performance reports. The corporation is also accountable to the financial institutions that give it financial resources (in terms of loans). Internally, the corporation operates Internally Delegated Area Management Contracts (IDAMCs), between its Head Office and Area Service Providers. The main objective of IDAMCs is to provide incentives for improved performance, through a mechanism linked to UfW, billing efficiency, staff per 1000 connections, metered connections and annual turnover. Performance-based pay systems have also been adopted and employees are accountable for their results. Thus, the corporation typifies the holding of its members responsible for their work, as is characteristic of NPM (Islam, 1993; Pollit et al., 1998). It also typifies the setting of goals against verifiable indicators, which is associated, by Yepes (1990), with enhancing performance.

Customer orientation: this was looked at in terms of NWSC's dependency on customer revenue, elicitation of customers' views, resolution of customers' complaints, involvement of customers in decision making and training of staff in customer management. At the time of data collection, in 2008, the corporation's financial report (2007/2008) indicated that it derived 95\% of its income from the levy of user fees. The interviews also revealed that employees are trained in customer management; there is a customer charter, specifying the nature of services that the corporation commits itself to provide; and, annually, the corporation conducts customer surveys. Besides, the corporation's offices have suggestion boxes that customers may use to engage the organization. Though it was also established that some customers' complaints are not promptly addressed, therefore, it can be concluded that the corporation has a strong customer orientation. This means that, consistent with Awortwi (2003)'s characterization of NPM, NWSC appreciates the link between its customers' satisfaction and its income and, thus, the need to enhance the former.

Market orientation: this was looked at in terms of internal competition, benchmarking and outsourcing. The findings were that the IDAMCs stimulate competition, as workers compete for managerial responsibility. The contracts contain incentives including rewarding good performance financially, which is why employees are likely to be interested in engaging in them. This is in consonance with Jaworski \& Koli (1990), Lavery (1999) and Warner \& Hedbon (2001). The interviewees indicated that the corporation undertakes benchmarking activities. It was also established that the corporation contracts out nearly $35 \%$ of its operational budget. However, the organization does not have a fully developed policy on contracting out, so contracting out is usually based on ad-hoc decisions. Even then, it is clear that the corporation has a significant market orientation. 
Customer satisfaction was looked at in terms of customers' contentment with the quantity and quality of water supplied; billing and payment systems; promptness of response to complaints; connection procedures; location and ambience of support offices; and continuity of servicebasing on Benington (2007)'s conceptualization of customer satisfaction as contentment with the benefit(s) derived from a service; and Tynan and Kingdom (2002)'s conceptualization of the attributes within which to appraise the quality of water services delivery respectively. The results are summarized in Table 2.

Table 2: Distribution of NWSC Customers by Contentment with the Corporation's Services $(\%, n=286)$

\begin{tabular}{|c|c|}
\hline Aspect of NWSC's Service Delivery & $\begin{array}{l}\text { Customers } \\
\text { Contented }\end{array}$ \\
\hline Water quantity & 75 \\
\hline Water quality & 58 \\
\hline Meter reading & 73 \\
\hline Prompt delivery of bills & 90 \\
\hline Method of payment & 88 \\
\hline Grace period for bill payment & 89 \\
\hline Location of NWSC offices & 67 \\
\hline Ambience of NWSC offices & 72 \\
\hline Promptness in restoring water supply in case of interruptions & 62 \\
\hline Observance of friendly environmental practices & 79 \\
\hline Procedures for new connections & 41 \\
\hline Billing quality & 48 \\
\hline Sensitizing customers on pricing, billing, and quality & 33 \\
\hline Reliability of water supply & 39 \\
\hline Responding to customer complaints & 45 \\
\hline
\end{tabular}

The results in Table 2 indicate that majority of the respondents expressed contentment with the quantity and quality of water; meter reading, delivery of bills, method of payment and grace period for bill payment; location and ambience of NWSC offices; promptness in restoring supply, in case of interruptions; and observance of friendly environmental practices. However, they also expressed discontentment with the procedures followed in procuring new connections; the quality of billing; sensitizing customers on pricing, billing and quality; the reliability of water supply; and promptness in responding to complaints. Considering that the respondents expressed contentment with ten (10) out of the fifteen (15) aspects of the corporation's service delivery studded, however, it was concluded that, overall, NWSC customers are satisfied. Indeed, $87 \%$ of them indicated that they would "agree" that the quality of the corporation's service and customer care are better than those of other service corporations in the country. This leads to the conclusion that the use of NPM in the corporation has increased customer satisfaction, which is in concurrence with Nickson and Franceys (2003), who observe that, the world over, the adoption of NPM techniques is enhancing the quality of water service delivery. Thus, it is recommended that the corporation increases its adherence to the principles of the management strategy, notably customer orientation, through addressing the aspects of its service delivery on which the respondents expressed discontentment. Grounded on the experience of NWSC, NPM is also recommended to similar corporations. 


\section{References}

Awortwi, N., 2003. Getting the fundamentals wrong: governance of multiple modalities of basic services delivery in three Ghanaian cities. PhD thesis. Maastricht: Institute of Social Studies, Shaker Publishing.

Batley, R., 1999. The role of government in adjusting economies: an overview of findings. [Online] Available at: http://www.idd.bham.ac.uk/research/Projects/Role of gov/workingpapers/paper41.htm.

Benington, J., 2007. In search of public value- beyond private choice. Coventry: Palgrave.

Bovaird, T., 2006. Developing new forms of partnership with the 'market' in the procurement of public services, Public Administration, 76 (4), pp. 695-712.

Gleick, P., 2002. Water in the $21^{\text {st }}$ Century. In: P. Gleick, ed. Water in crisis: a guide to the world's fresh water resources, New York: Oxford University Press.

Harrow, J., 2002. New Public Management and Social Justice: Just Efficiency or Equity as well? In: K., McLaughlin, S., Osborne and E., Ferlie, eds. New Public Management: current trends and future prospects. London: Routledge.

Hoffer, J., 1995. The challenge of effective urban water supply. University of Twente, Enschede.

Hood, C. 1991. A public management for all seasons, Public Administration, 69, pp. 3-19.

Hughes, O., 2006. The new pragmatism: moving beyond the debate over NPM. In: 10th Annual International Research Symposium on Public Management. Glasgow, Scotland 10-12 April 2006. Caledonian University: Glasgow.

Islam, N., 1993. Public enterprise reform: managerial autonomy, accountability and performance contracts. Public Administration and Development, 13, pp. 129-152.

Jaworski, B. J. and Kohli, A. K., 1993. Market orientation: antecedents and consequences, Journal of Marketing, 57 (3), pp. 53-70.

Kettl, D., 2000. The global public management revolution: a report on the transformation of governance. Washington DC: The Brookings Institute.

Kjellen, M., 2006. From public pipes to private hands: water access and distribution in Dar es Salaam Tanzania. PhD Thesis. Stockholm: Stockholm University.

Lavery K., 1999. Smart contracting for local government services: processes and experience. Westport: CT Preager.

Mugisha, S. and Berg, S., 2006. Turning around struggling state-owned enterprises in developing countries: the case of NWSC-Uganda. In: Reforming public utilities to meet the water and sanitation Millennium Development Goal. London: WaterAid and World Development Movement.

Okke, Braadbaart, Niels van Eybergen and Jan Hoffer, 2007. Managerial autonomy: does it matter for the performance of water utilities? Public Administration and Development; 27 (2), pp. 111 121.

Osborne, D. and Gaebler, T., 1992. Reinventing government: how the entrepreneurial spirit is transforming the public sector. Reading: Addison-Wesley.

Peters, B. G., 1996. The future of governing: four emerging models. Kansas: University Press of Kansas.

Pollitt, C., 1993. Managerialism and the public service: cuts or cultural change in the 1990s. $2^{\text {nd }}$ ed. Oxford: Blackwell.

Schwartz, K., 2006. Managing public utilities: an assessment of the bureaucratic and New Public Management models in the water supply and sanitation sectors in low and middle income countries. $\mathrm{PhD}$ thesis. Delft: UNESCO Institute of Water Education.

Schwartz, K., 2008. The new public management: the future for reforms in the African water supply and sanitation sector. Utilities Policy, 16, pp. 49-58.

Stoker, G., 2006., Public value management: a new narrative for networked governance? American Review of Public Administration, 36 (1), pp. 41- 57. 
Tynan, N. and Kingdom, W., 2002. Effective Water Service Provision, Second Draft, Washington D.C.: World Bank.

Van Dijk, M. P., 2006. Managing cities in developing countries; the theory and practice of urban management. Northampton: Edward Elgar.

Von Weizsacker, E. U., Young, O. R. and Finger, M., 2005. Limits to privatization: how to avoid too much of a good thing. London: Earthscan.

Walsh, K., 1995. Public services and market mechanisms: competition, contracting and the new public management. London: Macmillan.

Warner, M. and Hedbon R., 2001. Local government restructuring: privatisation and its alternatives; Journal of Policy analysis and Management, 20(2), pp. 315 - 336.

Yepes, G., 1990. Management and operational practices of municipal and regional water and sewerage companies in Latin America and the Caribbean. Washington DC: World Bank.

\section{ABOUT THE AUTHOR}

MAURICE MUKOKOMA is a senior lecturer in the Faculty of Business Administration and Management, Uganda Martyrs University. She holds an M Phil, MBA, ACCA and CIPS. She is a professional accountant and a specialist in Public management. She has published three articles on service delivery in local governments, higher education and private hospitals. She has also published a book on the motivation dilemma in Uganda. For correspondence please on this article please contact: galwomm@yahoo.co.uk 